\begin{tabular}{|l|l|l|}
\hline \multicolumn{2}{|c|}{ PublisherInfo } \\
\hline \hline PublisherName & $:$ & BioMed Central \\
\hline \hline PublisherLocation & $:$ & London \\
\hline \hline PublisherImprintName & $:$ & BioMed Central \\
\hline \hline
\end{tabular}

\title{
RNAi dissects signal pathway
}

\begin{tabular}{|l|l|l||}
\hline \multicolumn{2}{|c|}{ ArticleInfo } \\
\hline \hline ArticleID & $:$ & 4969 \\
\hline \hline ArticleDOI & $:$ & $10.1186 /$ gb-spotlight-20040624-01 \\
\hline \hline ArticleCitationID & $:$ & spotlight-20040624-01 \\
\hline \hline ArticleSequenceNumber & $:$ & 32 \\
\hline \hline ArticleCategory & $:$ & Research news \\
\hline ArticleFirstPage & $:$ & 1 \\
\hline \hline ArticleLastPage & $:$ & 3 \\
\hline \hline & & RegistrationDate : 2004-6-24 \\
\hline ArticleHistory & $:$ & OnlineDate \\
\hline \hline ArticleCopyright & $:$ & BioMed Central Ltd2004-6-24 \\
\hline \hline ArticleGrants & $:$ & \\
\hline \hline ArticleContext & $:$ & 130595511 \\
\hline \hline
\end{tabular}


In the first published real use of high-throughput RNAi screening in a laboratory setting, a group of researchers at the University of California, San Francisco, has identified novel negative and positive regulators of a Drosophila melanogaster signal transduction pathway.

Edan Foley and Patrick O'Farrell report their study of Drosophila's innate immune defense system in the June 22 PLoS Biology . To dissect the pathway, the team created a library of 7216 double-stranded Drosophila RNAs that interfered with most of the phylogenetically conserved genes (PLoS Biology 2004, DOI:10.1371/journal.pbio.0020203).

The authors identified numerous components of signal transduction, including negative and positive regulators of innate immune signaling, a hierarchy of gene action, and a novel gene, sickie - required for activation of a key component of the pathway, Relish.

"These double-stranded RNA messages are really powerful - and particularly powerful and easy to use in Dropsophila," O'Farrell said. "We can make any double-stranded RNA, pretty much, and we just pipette it on top of the cells and it inactivates the genes." He added that a graduate student might spend 5 or 6 years identifying one gene, isolating it and studying it, "and we have in several cases conducted entire screens in less than a month."

"This might be the first paper that took it to the next step and tried to tackle a particular pathway," said Neil Silverman, an assistant professor in the Department of Medicine at the University of Massachusetts Medical School, describing earlier publications using the technology.

Silverman expressed some reservations over the data. "I don't understand all the results," he said. "I have a hard time explaining some of their epistatic interactions. But it's incredibly powerful to be able to do genetics in a cell line. If you were doing this kind of experiment in flies, you would spend months in tracking down what the different mutants you isolated were," Silverman, who was not involved in the study, told us.

"The beauty of this paper is in the application of cutting-edge technology - high-throughput RNAi - in a very classical way," Anne Carpenter told us by E-mail. Carpenter, a faculty member at the Whitehead Institute for Biomedical Research, Cambridge, Mass., who was not involved in the study, said she believes that applying a similar approach genome-wide for a variety of nodes in the pathway would provide the field of systems biology with enough high-quality phenotypic data to have real hope of assembling entire signaling networks.

"I'm personally more biased towards genetic screens in the fly, but I think this is great," said Louisa $\mathrm{Wu}$, an assistant professor at the Center for Biosystems Research at the University of Maryland Biotechnology Institute. Wu, who was not involved in the study, also expressed some reservations about the interpretation of the results. "I think you have to careful about interpretations of epistasis because unless you know you are completely knocking out function of the gene, you could have genes that are knocked down a little bit, but then you can't absolutely say that the effect you see is upstream or downstream," she said. But, she added, "I do like the fact that they identified negative regulators because that's something that in the past hasn't been extensively looked for." 
"One thing that this paper highlights is that there are probably multiple layers of regulation in this pathway. Some of the components may have multiple roles in the different steps in the pathway - so I think it's going to be a much more complicated network than we as a field have really been considering," said Silverman.

\section{References}

1. Patrick O'Farrell, [http://www.ucsf.edu/poflab/Pat.html]

2. PLoS Biology, [http://www.plosbiology.org/]

3. Neal Silverman, [http://www.umassmed.edu/igp/faculty/silverman.cfm]

4. Anne Carpenter, [http://csbi.mit.edu/faculty/Members/AnneCarpenter]

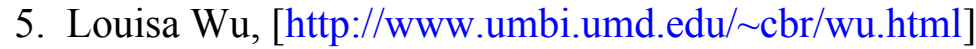

This PDF file was created after publication. 